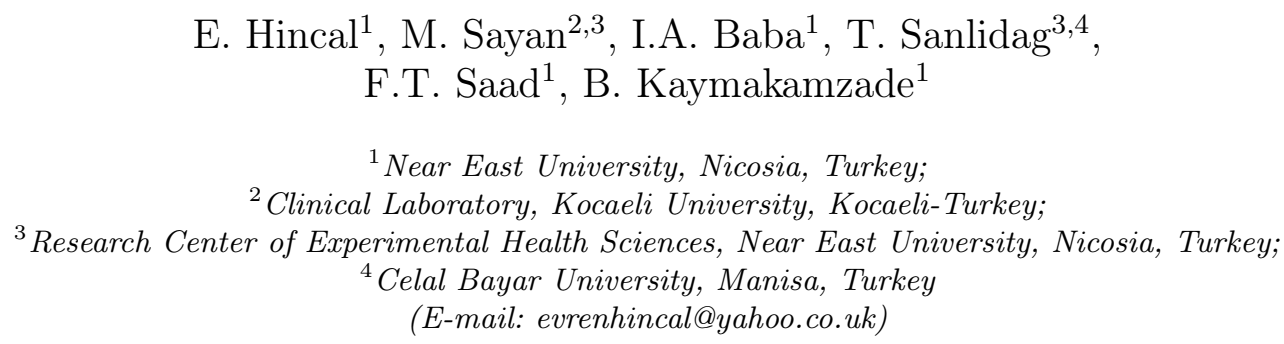

\title{
Dynamics of HIV-1 infected population acquired via different sexual contacts route: a case study of Turkey
}

\begin{abstract}
This paper aims to study the transmission dynamics of HIV/AIDS in heterosexual, men having sex with men (MSM)/bisexuals and others in Turkey. Four equilibrium points were obtained which include disease free and endemic equilibrium points. The global stability analysis of the equilibria was carried out using the Lyapunov function which happens to depend on the basic reproduction number $R_{0}$. If $R_{0}<1$ the disease free equilibrium point is globally asymptotically stable and the disease dies out, and if $R_{0}>1$, the endemic equilibrium point is stable and epidemics will occur. We use raw data obtained from Kocaeli University, PCR Unit, Turkey to analyze and predict the trend of HIV/AIDS among heterosexuals, MSM/bisexual, and others. The basic reproduction number for heterosexuals, MSM/bisexuals, and others was found to be $1.08,0.6719$, and 0.050 , respectively. This shows that the threat posed by HIV/AIDS among heterosexuals is greater than followed by MSM/bisexuals, and than the others. So, the relevant authorities should put priorities in containing the disease in order of their threat.
\end{abstract}

Keywords: HIV/AIDS, Basic reproduction number, Equilibrium point, Stability, Lyapunov function, MSM, Heterosexual.

\section{Introduction}

One of the major factors leading to the prevalence and epidemics of HIV/AIDS is the increase in the population of men having sex with men (MSM). Most of the countries affected are the United States, Canada, Australia, and New Zealand. However, in some of the under-developed and developing countries, heterosexual sex, injection drug use, and/or transfusion of contaminated blood remain the main mode of transmission of the disease [1] and [2]. A sudden rise of HIV cases in MSM was detected in the continent of Africa, Asia, South America, and Eastern Europe [3]. According to a report in China, the rates of HIV infection in MSM is increasing dramatically, while other means of transmissions are either decreasing or remaining under control. The rate among MSM increased from $12.2 \%$ in 2007 to $35.5 \%$ in 2009. As a result, China is declared as one of the countries experiencing the rise of HIV epidemics in MSM [4].

In a report by the European surveillance network, Euro HIV, the number of new HIV cases in MSM rises from 2538 to 5016 during 1999-2006 across 13 Western European countries. This signifies almost 100\% increase in new cases among MSM [5]. Central European countries experienced low prevalence of new HIV cases among MSM, but a sudden increase started in the year 1999 with 130 cases. This number increases by more than $100 \%$ in 2006, where 295 new cases were recorded. The countries in this region contributed at least $50 \%$ of the total number of HIV cases in MSM recorded across Europe. In Eastern Europe, not more than 1\% of newly reported cases were in MSM, and no increase was discovered over time [6]. The annual HIV incidence rate in the Netherlands was $1.2 \%$ for a period of 6 years (1999-2005). However, a relative increase was noticed among MSM [7].

In 2008, the US Centers for Disease Control and Prevention (CDC) reported that, around 1.1 million people were infected with HIV/AIDS in 2006 in the United States. Almost half (48.1 percent) of this reported figure were MSM. In the same year, CDC also stated that the number of new cases of HIV/AIDS in MSM increased to $8.6 \%$ during 2001-2006. In black MSM, an increase in the number of newly HIV/AIDS infected individuals was reported from 2001-2006. Most of the victims were young adults aged 13-24 years; which recorded a 93.1\% increase. Despite the fact that the blacks forms just $13 \%$ of the US population, the number of HIV/AIDS cases diagnosed in black MSM aged 13-24 years (7658) was at least twice the number diagnosed in whites (3221) [8]. 
According to a report in 2006, 56,300 new adult HIV infections were recorded, of which 53\% were in MSM. Among the new HIV infections in men, $72 \%$ were in MSM, and of new infections in MSM, $46 \%$ were in whites, $35 \%$ were in blacks and $19 \%$ were in Hispanics. Therefore, the estimated HIV incidence among black MSM was 5.9 times bigger than among white MSM [9].

Mathematical models help to study the dynamics, spread and control of infectious diseases. It highlights and explains the possible outcome of an epidemic and aids in suggesting the various control measures. Kermarck and McKendrick in 1927 formulated an SIR model which studied the dynamics of infectious diseases [10]. The most important parameter that determines the outcome of an epidemic is the basic reproduction ratio $\left(R_{0}\right)$. It is the number of secondary infection caused by a single infective individual in a completely susceptible population. If the basic reproduction ratio is less than one, then there is not going to be an epidemic, which means that the disease will die out. Otherwise, an epidemic will occur [11] and [12]. Many mathematical models in literature have studied the dynamics of HIV/AIDS [13].

Our aim in this research is to study the dynamics of HIV/AIDS among heterosexuals, MSM/bisexuals, and others in Turkey. We use data obtained from Kocaeli University, PCR Unit, Turkey to analyze and predict the trend of HIV/AIDS among these groups. This is because Kocaeli University has the largest HIV data collection center in Turkey.

\section{Model formulation}

The model is given by the system of differential equations as follows, where the meaning of parameters/variables is given in Table 1 .

$$
\left\{\begin{array}{c}
\frac{d S}{d t}=\Lambda-\beta_{1} S H_{1}-\beta_{2} S H_{2}-\beta_{3} S H_{3}-\mu S \\
\frac{d H_{1}}{d t}=\beta_{1} S H_{1}-(\mu+v) S \\
\frac{d H_{2}}{d t}=\beta_{2} S H_{2}-(\mu+v) S \\
\frac{d H_{3}}{d t}=\beta_{3} S H_{3}-(\mu+v) S
\end{array}\right.
$$

$S(0)>0, H_{1}(0) \geq 0, H_{2}(0) \geq 0, H_{3}(0) \geq 0$.

Table 1

Meaning of parameters and variables of model (1)

\begin{tabular}{|c|l|}
\hline Parameters/Variables & Meaning \\
\hline $\mathrm{S}$ & Population of susceptible \\
\hline$H_{1}$ & HIV positive of heterosexual population \\
\hline$H_{2}$ & HIV positive of MSM population \\
\hline$H_{3}$ & HIV positive of other population \\
\hline$\Lambda$ & Recruitment rate \\
\hline$\frac{1}{v}$ & Duration spent in the HIV stage \\
\hline$\frac{1}{\mu}$ & Life expectancy \\
\hline$\beta_{1}$ & Incidence rate between heterosexuals \\
\hline$\beta_{2}$ & Incidence rate between MSM \\
\hline$\beta_{3}$ & Incidence rate between others \\
\hline
\end{tabular}

In our model, $\mathrm{S}(0)$ is considered to be the whole population in a specific year, $H_{2}$ consists of both MSM and bisexuals HIV positive population, and $\beta_{2}$ is the transmission rate of HIV through MSM or bisexuals. Moreover, we refer to HIV positive of other population as those that acquire the disease through contaminated blood transfusion, contact with infected sharp objects and so on.

\section{Existence of Equilibria}

Equating the equations in (1) to zero and solving simultaneously we find four equilibrium points. They are as follows. Disease free equilibrium point $E_{0}=\left(\frac{\Lambda}{\mu}, 0,0,0\right)$, which always exists and endemic equilibria. 


$$
E_{1}=\left(\frac{\mu+v}{\beta_{1}}, \frac{\Lambda \beta_{1}-\mu(\mu+v)}{\beta_{1}(\mu+v)}, 0,0\right), E_{2}=\left(\frac{\mu+v}{\beta_{2}}, 0, \frac{\Lambda \beta_{2}-\mu(\mu+v)}{\beta_{2}(\mu+v)}, 0\right), \text { and } E_{3}=\left(\frac{\mu+v}{\beta_{3}}, 0,0, \frac{\Lambda \beta_{3}-\mu(\mu+v)}{\beta_{3}(\mu+v)}\right) .
$$

The endemic equilibria are biologically meaningful (exists) when $\frac{\beta_{1} \Lambda}{\mu(\mu+v)}>1, \frac{\beta_{2} \Lambda}{\mu(\mu+v)}>1$, and $\frac{\beta_{3} \Lambda}{\mu(\mu+v)}>1$, respectively.

\section{Basic Reproduction Ratio}

Basic reproduction ratio is the number of secondary infections caused by a single infective individual in a completely susceptible population. It is denoted by $R_{0}$. We use the next generation of matrix (NGM) method to compute the basic reproduction ratio and it is given by

$$
R_{0}=\max \left[R_{1}, R_{2}, R_{3}\right]
$$

where $R_{1}=\frac{\beta_{1} \Lambda}{\mu(\mu+v)}, R_{2}=\frac{\beta_{2} \Lambda}{\mu(\mu+v)}$, and $R_{3}=\frac{\beta_{3} \Lambda}{\mu(\mu+v)}$.

\section{Global Stability Analysis of the Equilibria}

Theorem 1. $E_{0}$ is globally asymptotically stable when $R_{0}<1$.

Proof. We consider the following Lyapunov function; $V=\left(S-S_{0} \ln S\right)+H_{1}+H_{2}+H_{3}+C$, where $C=S_{0} \ln S_{0}-S_{0}$. Hence,

$$
\begin{gathered}
\frac{d V}{d t}=\left(1-\frac{S_{0}}{S}\right) \frac{d S}{d t}+\frac{d H_{1}}{d t}+\frac{d H_{2}}{d t}+\frac{d H_{3}}{d t}= \\
=\left(1-\frac{S_{0}}{S}\right)\left(\Lambda-\beta_{1} S H_{1}-\beta_{2} S H_{2}-\beta_{3} S H_{3}-\mu S\right)+\left(\beta_{1} S H_{1}-(\mu+v) H_{1}\right)+\left(\beta_{2} S H_{2}-(\mu+v) H_{2}\right)+\left(\beta_{3} S H_{3}-(\mu+v) H_{3}\right)= \\
=\mu S_{0}\left(2-\frac{S_{0}}{S}-\frac{S}{S_{0}}\right)+\left(\beta_{1} S_{0}-(\mu+v)\right) H_{1}+\left(\beta_{2} S_{0}-(\mu+v)\right) H_{2}+\left(\beta_{3} S_{0}-(\mu+v)\right) H_{3} .
\end{gathered}
$$

Therefore $\frac{d V}{d t}<0$ if $\beta_{1} S_{0}-(\mu+v)<0, \beta_{2} S_{0}-(\mu+v)<0$ and $\beta_{3} S_{0}-(\mu+v)<0$ which means $R_{0}<1$.

Theorem 2. The endemic equilibrium point $E_{1}$ is globally asymptotically stable when $R_{1}>1, R_{2}<1$ and $R_{3}<1$

Proof. The proof is similar to Theorem 1 by considering the following Lyapunov function;

$$
V=\left(S-S^{*} \ln S\right)+\left(H_{1}-H_{1}^{*} \ln H_{1}\right)+H_{2}+H_{3}+C, \text { where } C=S^{*} \ln S^{*}-S^{*}-H_{1}^{*}+H_{1}^{*} \ln H_{1}^{*} .
$$

Theorem 3. The endemic equilibrium point $E_{2}$ is globally asymptotically stable when $R_{1}>1, R_{2}>1$ and $R_{3}<1$.

Proof. The proof is similar to Theorem 1 by considering the following Lyapunov function;

$$
V=\left(S-S^{*} \ln S\right)+H_{1}+H_{2}-H_{2}^{*} \ln H_{2}+H_{3}+C, \text { where } C=S^{*} \ln S-S^{*}-H_{2}^{*}+H_{2}^{*} \ln H_{2}^{*} .
$$

Theorem 4. The endemic equilibrium point $E_{3}$ is globally asymptotically stable when $R_{1}<1, R_{2}<1$ and $R_{3}>1$.

Proof. The result can be achieved using the following Lyapunov function;

$$
V=\left(S-S^{*} \ln S\right)+H_{1}+H_{2}+\left(H_{3}-H_{3}^{*} \ln H_{3}+C, \text { where } C=S^{*} \ln S^{*}-S^{*}-H_{3}^{*}+H_{3}^{*} \ln H_{3}^{*} .\right.
$$

\section{Numerical Simulations}

We use the raw data obtained from Kocaeli University, PCR Unit, Turkey from January 2016 to March 2017. This unit is a collection center for HIV in Turkey. Table 2, 3, Pictures 1 and 2 show the outcomes of the analysis of the model.

The dynamics of the heterosexuals, MSM/bisexuals and others is given by Picture 1 .

Analysis of the model with incidence rates

\begin{tabular}{|c|c|c|}
\hline$H_{1}$ & $H_{2}$ & $H_{2}$ \\
\hline$\beta_{1}$ & $\beta_{2}$ & $\beta_{3}$ \\
\hline 1.863 & 1.155 & 0.086 \\
\hline
\end{tabular}


Analysis of the model with Basic reproduction ratios

\begin{tabular}{|c|c|c|}
\hline$H_{1}$ & $H_{2}$ & $H_{2}$ \\
\hline$R_{1}$ & $R_{2}$ & $R_{3}$ \\
\hline 1.08 & 0.6719 & 0.050 \\
\hline
\end{tabular}

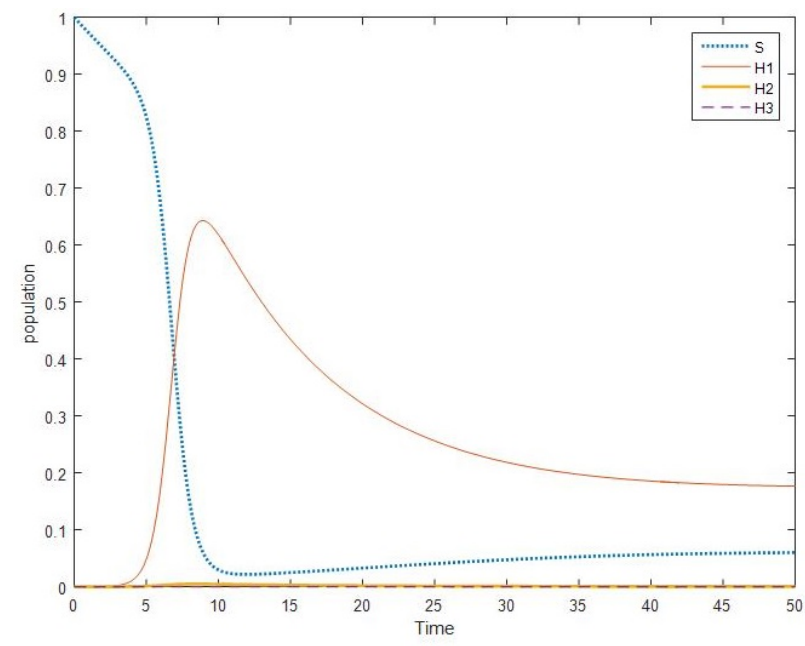

Picture 1. Parameter values are $\beta_{1}=1.863, \beta_{2}=1.155, \beta_{3}=0.086, \mu=0.055, \Lambda=0.023$ and $v=0.063$

\section{Discussion and Conclusion}

We constructed a mathematical model that studies the transmission dynamics of HIV/AIDS in heterosexuals, MSM/bisexuals and others. The basic reproduction ratio was computed using the next generation matrix method. Four equilibrium points were obtained which include disease free and endemic equilibrium points. The global stability analysis of each of the equilibria was conducted using the Lyapunov function, and the stability of the equilibrium points depends on the basic reproduction ratio $R_{0}$. If the basic reproduction ratio is less than one, there will be no epidemic, which means the disease will die out, otherwise, an epidemic will occur.

From table 3, the basic reproduction ratios of heterosexuals, MSM/bisexuals, and others are 1.08, 0.6719, and 0.050 , respectively. Based on the table and Picture 1, the epidemics will occur in the heterosexuals, while no epidemics will occur in the MSM/bisexuals and others. Although no epidemics will occur in MSM, but the basic reproduction ratio is close to 1 , so if care is not taken in MSM/bisexuals epidemic may occur as time goes on. The threat posed by HIV/AIDS through heterosexuals is greater, than followed by MSM, and than the others. However, this is subject to the initial values which can change the nature of the graph, because, normally the data is usually collected at the early stages of the infection (trauma stage), so patients may hide their sexual status or refuse to give accurate information. We therefore recommend the use of IVD drug data in any community with similar settings as that of Turkey like the Asian countries, African countries, and Islamic countries for data collection.

The relevant authorities should put priorities in containing the disease in order of their threat. It is also evident that the incidence rate plays a vital role in posing this threat as can be seen from Table 2, therefore to contain the disease it is advisable to employ the appropriate measures in decreasing the incidence rates. Finally, Picture 1 shows the prediction of these epidemics for the three cases in 50 years.

Istanbul is the most populous city and center for tourism in Turkey. It is one of the largest cities in Europe and considered to be the home of immigrants. Hence, the population in Istanbul has more freedom, is well mixed, versatile, and tolerant. These are among the major factors that give rise to the increase in MSM population in Istanbul because people are not afraid to say their sexual status. Therefore, tourism, immigration, and increase in MSM population make Istanbul the center for the spread of HIV infection in Turkey. 


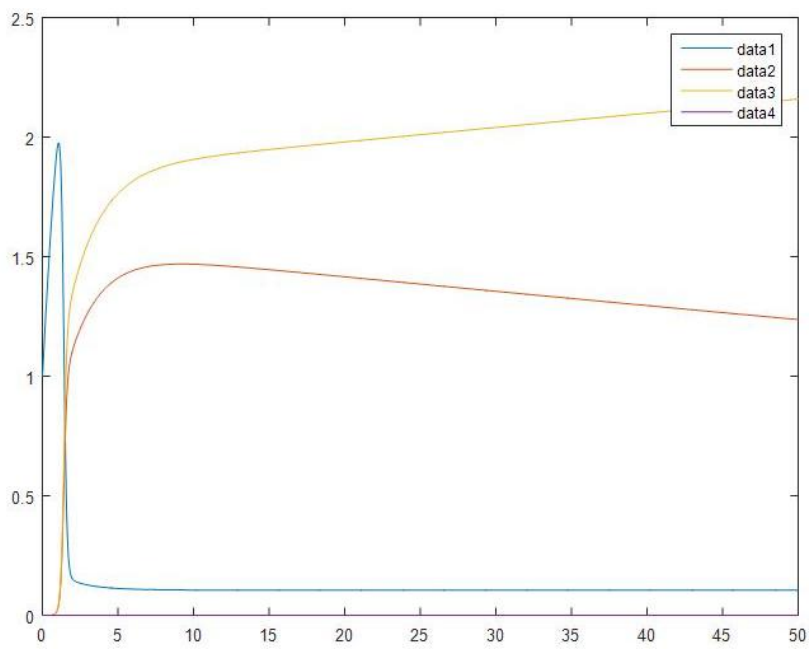

Picture 2. Parameter values are $\beta_{1}=4.44, \beta_{2}=4.51, \beta_{3}=0.19, \mu=0.41, \Lambda=1.65$ and $v=0.063$

The aforementioned reasons and facts served as our motivation to consider the data collected for Istanbul only and put it in our model in order to analyze the dynamics of the transmission route of HIV. Picture 2 shows this dynamics and predicts what will possibly happen in the next 50 years. It can be observed that the transmission of HIV in MSM is increasing while the transmission via heterosexuals and others is decreasing.

\section{References}

1 Sayan, M., \& et al. (2012). Journal of the International AIDS Society, 15, 1-1.

2 Sayan, M., Willke, A., Ozgunes, N., \& Sargın, F. (2013). Japanese journal of infectious diseases, 66, 306-311.

3 Beyrer, C. (2010). Clinical Infectious Diseases, 50, 108-113.

4 Zhang, L., \& et al. (2013). The Lancet infectious diseases, 13, 955-963.

5 Van Griensven, F., van Wijngaarden, J., Baral, S., \& Grulich, A. (2009). Current Opinion in HIV and AIDS, 4, 300-307.

6 Elford, J., \& et al. (2009). Eurosurveillance, 14, 19414.

7 Giuliani, M., \& et al. (2005) Aids, 19, 1429-1431.

8 Sayan, M., Kaptan, F., Ormen, B., \& Türker, N. (2014). Mikrobiyoloji bulteni, 48, 160-167.

9 Çelen, M.K., \& et al. (2015).Asian Pacific Journal of Tropical Biomedicine, 5, 773-777.

10 Sayan, M., \& et al. (2016). HIV clinical trials, 17, 109-113.

11 Sayan, M., \& et al. (2016). AIDS research and human retroviruses, 32, 26-31.

12 Centers for Disease Control and Prevention (CDC and others MMWR. Morbidity and mortality weekly report, (2008). 57, 1073.

13 Isea, R., \& Lonngren, K.E. (2013). Gen, 19, 83-87.

Э. Хинкал, М. Саян, И.А. Баба, Т. Санлидаг, Ф.Т. Саад, Б. Каймакамзаде

\section{Әрқилы жыныстық қатынастар арқылы ВИЧ-1 инфекциясын жұқтырған халықтың динамикасы: Түркияда жүргізілген зерттеу}

\footnotetext{
Мақала Түркиядағы гетеросексуалдар, ер адамдар мен ер адамдар арасындағы сексуалдық қатынас (ECE)/бисексуалдар және басқа да адамдардың арасында ВИЧ/СПИД инфекциясының таралу динамикасын зерттеуге арналған. Аурулардан таза және эндемиялық тепе-теңдік нүктелерін қамтитын
} 
төрт тепе-теңдік нүктесі табылған. Негізгі көбею санынан $R_{0}$ тәуелді Ляпунов функциясын пайдалану арқылы тепе-теңдік орнықтылығына ауқымды талдау жасалды. Егер $R_{0}<1$ болса, ауруы жоқ тепе-теңдік нүктесі асимптотикалық тұрғыдан ауқымды орнықты болады да, аурулар жойылады. Ал $R_{0}>1$ болса, эндемиялық тепе-теңдік нүктесі тұрақты кейіпке ие болады да, эпидемиялар болып тұрады. Гетеросексуалдар, ЕСЕ/бисексуалдар және басқа да адамдардардың арасында ВИЧ/СПИД инфекциясының таралу тенденциясына талдау және болжам жасау үшін біз Коджаэли университетінен, Түркиядағы орталығынан алынған өңделмеген мәліметтерді пайдаланылды. Гетеросексуалдар, ЕСЕ/бисексуалдар және басқалардың көбеюінің базалық саны тиісінше 1.086, 0.6719, 0.050 болатыны анықталды. Бұл мәліметтерден, басқа топтарға қарағанда, ВИЧ/СПИД қатері гетеросексуалдар арасында жоғары екені байқалды. Сондықтан тиісті мекемелер ауру қоздырғыштарын тежеу мәселесінде басымдылықтар белгілеуі тиіс.

Кілт сөздер: ВИЧ/СПИД, көбеюдің базалық саны, тепе-теңдік нүктесі, тұрақтылық, Ляпунов функциясы, ЕСЕ, гетеросексуалды.

\author{
Э. Хинкал, М. Саян, И.А. Баба, Т. Санлидаг, Ф.Т. Саад, Б. Каймакамзаде
}

\title{
Динамика населения, инфицированного ВИЧ-1, приобретенного через разные половые контакты: исследование в Турции
}

\begin{abstract}
Статья направлена на изучение динамики передачи ВИЧ/СПИДа среди гетеросексуалов, мужчин, имеющих секс с мужчинами (MCM)/бисексуалов и других лиц в Турции. Получены четыре точки равновесия, которые включают свободные от болезней и эндемичные точки равновесия. Глобальный анализ устойчивости равновесий проводился с использованием функции Ляпунова, которая зависит от основного числа воспроизведения $R_{0}$. Если $R_{0}<1$, точка равновесия без болезней является глобально асимптотически устойчивой, болезнь вымирает, а если $R_{0}>1$, точка эндемического равновесия стабильна - будут происходить эпидемии. Авторами использованы необработанные данные, полученные из Университета Коджаэли, ПЦР, в Турции для анализа и прогнозирования тенденции к ВИЧ/СПИДу среди гетеросексуалов, МСМ/бисексуалов и других. Было установлено, что базовое число воспроизведения гетеросексуалов, МСМ/бисексуалов и других было 1.08, 0.6719 и 0.050 соответственно. Это свидетельствует о том, что угроза, которую представляет ВИЧ/СПИД среди гетеросексуалов, выше, чем МСM/бисексуалы. Таким образом, соответствующие органы должны поставить приоритеты в сдерживании болезни в порядке их угрозы.
\end{abstract}

Ключевые слова: ВИЧ/СПИД, базовый номер воспроизводства, точка равновесия, стабильность, функция Ляпунова, МСМ, гетеросексуальный. 